\title{
ХУЧТЭЙ ХОЛБООСТ МУЖААС СУЛ ХОЛБООСТ МУЖ РУУ ШИЛЖИХ ШИЛЖИЛТИЙГ ТЭГ БУС ТЕМПЕРАТУРТ SU(2) ЛАТТИС ГЭЙЖ ОНОЛООР СУДЛАХ НЬ
}

\author{
Ч. Содбилэг, Г.Энхтуяа ${ }^{1 "}$ \\ ${ }^{1}$ ШУА-ийн Физик Технологийн Хүрээлэн, Монгол Улс \\ Цахим шуудан: enkaа_tuуaа@yahoo.com
}

\section{ХУРААНГУЙ}

ЭнэхүҮ судалгааны ажлаар тэг температуртай уед конфайнмент фазад илэрдэг үзэгдэл болох глюоны урсгальн хоолойн таталияльн коэффицуиентийн утаа нь хүчтэй холбоост мужаас сул холбоост муж руу иилждэг иилжилтийг тэг бус температурт буюу өөрөөр хэлбэл тодорхой температуртай тохиолдолд SU(2) иээвэр латтис гэйж онолоор симуляцุи хийн ажиглахыг зорилоо.

Бид глюонь урсгальн хоолойн өргөнийг урсгальлн хоолой доторх орньл хүчлэгийн хромо цахилгаан компонентийн хөндлөн түгэлтээс гарган авч кварк хоорондын зай ба температураас хамаарах хамаарльг гаргав. Кваркуудын хоорондын зайг ихэсгэхэд глюоны урсгальн хоолойн өргөн өргөсдөгийг дахин батлан харуулсан. Харин холбоосын тогтмольнн утгыг ихэсгэхэд урсгальн хоолойн өргөн тодорхой нэг утга хүртэл монотон байж байгаад тухайн утганд огцом өргөсөж байгааг харуулсан болно.

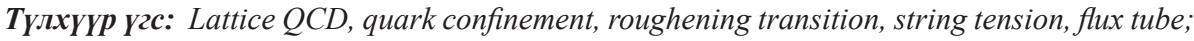

\section{ОРШИЛ}

Квант хромодинамикийн (КХД) онолын судалгаанд кварк конфайнмент үзэгдлийн механизмыг ойлгох нь маш чухал асуудал байдаг. Конфайнмент гэдэг нь кваркууд хоорондоо ойр зайтай байхад квант электродинамикийн диполийн орон шиг холбоосын тогтмолын логарифм хамааралтай Кулон-төст потенциал давамгайлдаг бол хол зайд потенциал нь зайнаас шугаман хамааралтай өсдөг үзэгдэл юм. Энэхүу потенциал нь зайнаас шугаман хамааралтай өсөх үеийн коэффициентийг таталцлын коэффициент $(\boldsymbol{\sigma})$ гэж нэрлэдэг. Тодорхой температур болон нягттай квант хромодинамикийн судалгаа нь хүнд ионы мөргөлдөөний туршилт, мөн түүнчлэн маш олон астрофизикийн асуудлуудад хамааралтай юм. Тодорхой температуртай тохиолдолд потенциалыг тооцоход тухайн нэг температурт потенциал зайнаас шугаман хамаардаг хамаарал хадгалагддаг боловч температур ихсэхэд энэ хамаарлын хэвтээ тэнхлэгтэй үүсгэх налалтын өнцөг буурч байгааг харуулсан олон судалгаанууд 
байдаг [1-4]. Энэ шугаман потенциал нь кваркуудын хооронд үүсдэг глюоны орны хоолойн төрх байдлаас шалтгаалж үүсдэг бөгөөд хоорондоо тодорхой зайд байгаа статик кваркуудын хоорондох хүч юм. Тоон тооцоололд энэ хүчийг зөвхөн харьцангуй бага $q \bar{q}$ зайн тохиолдолд л хэмжиж чаддаг. Кваркуудын хоорондох зай нь латтисын алслалт $a$-аaс хамаарах бөгөөд $a$-г сонгох нь бэрхшээлтэй асуудлуудын нэг юм. $a$-г хэтэрхий их байхаар сонговол эргээд тасралтгүй физик рүү шилжихэд бэрхшээлтэй байдаг бол, хэтэрхий нарийн байхаар сонговол бага хэмжээтэй латтис дээр хүчний асимптотик хэлбэрийг харах боломжгүй болдог.

Латтис дээр потенциалыг

$$
V(R)=-\lim \left[\frac{1}{T} \ln W(R, T)\right]
$$

гэж томъёолдог ба энд $W(R, T)$ нь огторгуй, хугацааны өргөсөлт нь тус тус $R, T$ байх Вилсоны гогцооны магадлалын утга.

Вилсоны гогцооны магадлалын утга конфайнмент фазад талбайн хуулиар $(\sigma R T)$

$$
W(R, T)=e^{-\sigma R T-\alpha(R+T)+\gamma}
$$

хэлбэртэй байна. Эндээс бид Кройцын харьцааг [5]

$$
\chi(R, T)=-\ln \left(\frac{W(R, T) W(R-1, T-1)}{W(R, T-1) W(R-1, T)}\right)
$$

судлан -г ялгаж чадна.

Өөрөөр хэлбэл, хэрэв Вилсон гогцоо нь тэгшитгэл 2-т өгөгдсөн аргаaр $R$, $T$-с хамаардаг бол $\chi(R, T)$ эдгээр хувьсагчуудаас үл хамаарах болж глюоны урсгалын хоолойн таталцлын коэффициенттэй давхцдаг.

Таталцлын коэффициент $\sigma$-ийн жинхэнэ утгыг одоо болтол тогтоогоогүй байгаа бөгөөд латтис симуляцаар түүний бусад физик хэмжигдэхүүнүүдээс хэрхэн хамаардаг хамаарлыг тодорхойлсон байдаг. Одоог хүртэл $\boldsymbol{\sigma}$-г тодорхойлохын тулд өөр өөр олон аргаар оролдсоор байгаа юм. Тухайлбал, $\boldsymbol{\sigma}$ нь гэйж групуудын хэмжээс тус бүрийн хувьд өөр өөр утгатай байдаг. Кварк конфайнментийн механизм нь КХД ба SU(N) цэвэр гэйж онолуудад нэлээд төсөөтэй юм. КХД-ийн онолд бодит утга нь $N=3$ байдаг. Гэвч $\mathrm{SU}(\mathrm{N})$ цэвэр гэйж онол нь конфайнментийг илүҮ сайн ойлгох ерөнхий нөхцлийг бидэнд өгдөг. Тухайлбал, $N>3$ болоход ялгаатай таталцлын коэффициентүүд бүхий глюоны урсгалын хоолойн шинэ хэлбэрүүд гарч ирдэг.

Түүнчлэн саяхан 2012 онд Кардосо, Бикудо [6] нар таталцлын коэффициентийг кварк-антикварк хосын өнгөөр дундажлагдсан чөлөөт энергээс тооцож гаргасан ба латтисын эзлэхүүн өөр өөр байх тохиолдолд эзлэхүүнээс хамааруулан Зураг 1-д зурсан байна. Тэд бага эзлэхүүнтэй латтисуудын хувьд эзлэхүүн ихсэхэд таталцлын коэффициент ихсэж байсан бол латтисын эзлэхүүн томрох тусам таталцлын коэффициентэд эзлэхүүний үзүүлэх нөлөө алга болж байна хэмээн дүгнэсэн. 


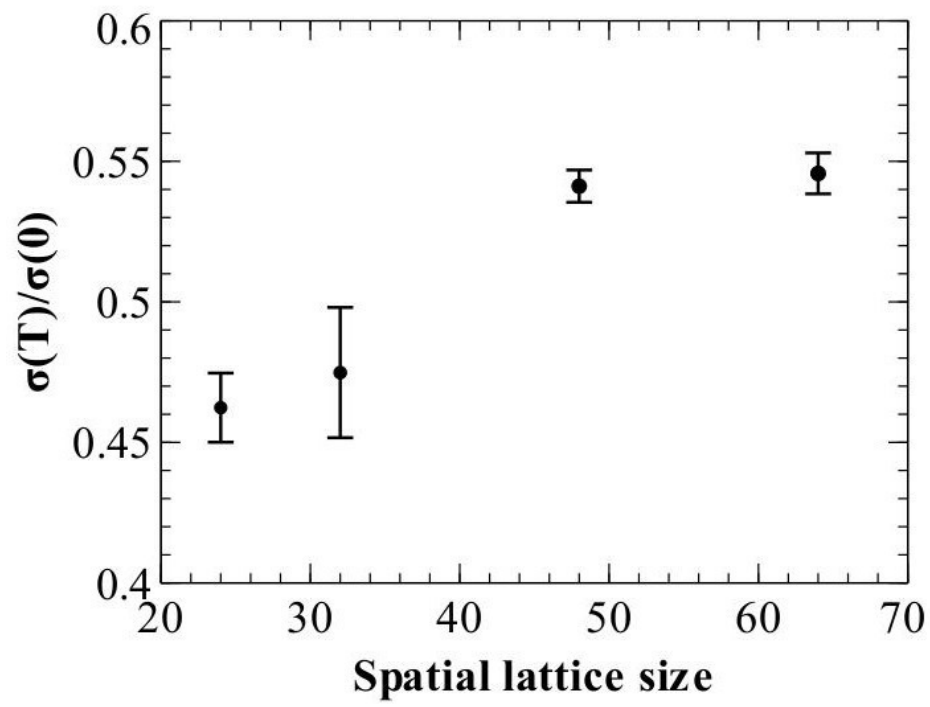

Зураг 1: Таталильюн коэффициент латтисын орон зайн эзлэхүҮнээс хамаарах хамаарал [6].

Мөн [6]-д $\sigma$ (Т)-ийн критик муруйг температураас хамааруулан судалсан. Тэд 0.5 Тс утганд таталцлын коэффициент тэг температуртай үеийн таталцлын коэффициент $\left(\boldsymbol{\sigma}_{0}\right)$-тэй тэнцүу болж байгаа бөгөөд түүнээс цааш температур ихсэхэд буурч байгааг харуулсан. Ийнхүүтаталцлын коэффициентийн утгыг тодорхойлох оролдлогуудын явцад конфайнмент мужид энэтаталцлын коэффициентийн шинж чанар өөрчлөгдөж байгаа нэгэн шилжилт болж байгааг ажигласан. Үүнийг roughening transition гэж нэрлэсэн бөгөөд энэ бол гадаргуу дээрх roughening шилжилтийн төрлийн үзэгдэл юм. Roughening бол гурван хэмжээст статистик механикт бидний маш сайн мэддэг үзэгдэл бөгөөд хангалттай их энергитэй үед тохиолддог хоёр фазын хоорондох интерфэйсийн делокализацийг тайлбарладаг [7].

Энэ үзэгдлийг абелын $U(1), Z(N)$ ба абелын бус $S U(N)$ гэйж групуудын хувьд 3 ба 4 хэмжээст тохиолдлуудад мөн дурын хэмжээсэнд гэх зэргээр олон өөр тохиолдлуудад судалсан [8-12]. Латтис КХД-ийн онолд энэ шилжилтийн үед глюоны орны хоолойн өргөн сарнидаг ба хоолойн гадаргуу бүхэлдээ делокализаци болдог боловч roughening температурын орчимд таталцлын коэффициент тэг болдоггүй тодорхой ямар нэгэн утгатай байдаг.

Энэ үзэгдэл бол конфайнмент фазаас деконфайнмент фазад шилжих шилжилт биш юм. Учир нь Вилсон гогцоо талбайн хуулиар тодорхойлогддог ба таталцлын коэффициентийг тэг биш гэж авч үзэж байвал кварк конфайнмент хадгалагдаж байна гэж үздэг.

Мөн конфайнмент нь глюоны орны хоолойн хэлбэр, бүтэцтэй шууд холбоотой учраас конфайнментийн үзэгдлийг ойлгохын тулд үндсэндээ глюоны урсгалын хоолой бусад физик хэмжигдэхүүнээс хэрхэн хамаарч хувирч өөрчлөгдөж байгааг судлах хэрэгтэй.

Энэ ажил нь тодорхой температуртай үед, конфайнмент фазад глюоны урсгалын хоолойн өргөн холбоосын тогтмол буюу температураас хэрхэн хамаарч байгааг харахыг зорисон юм. Өөрөөр хэлбэл тэг температурт болдог глюоны урсгалын хоолойн өргөн сарних үзэгдэл тодорхой температуртай тохиолдолд ажиглагдах уу?, мөн тэг температурт $\beta \approx 1.9$ дээр сарнидаг сарнил тодорхой температурт холбоосын 
тогтмолын ямар утганд сарних вэ?, тэг температуртай үеийнхтэй адил байх уу? эсвэл өөр байх уу? зэрэг асуултуудад хариулт авах зорилготой юм.

\section{ХУЧТЭЙ ХОЛБООСТ ЗАДАРГАА}

Хөндөх онолыг хэрэглэж болдоггүй зарим үзэгдлүүд байдаг бөгөөд жишээлбэл, динамикмассынүүсгэгч,кваркконфайнмент гэх мэт юм. Тиймээс хөндөх бус аргуудыг шаарддаг. Энэ хөндөх бус аргуудын нэг нь хүчтэй холбоост задаргааны арга юм. Энэ арга нь латтис холбоосын тогтмол ( $\beta)$-ийн зэрэгт цуваагаар задардаг. Хүчтэй холбоост задаргаа нь латтис онолоор хязгаарлагддаг бөгөөд тасралтгүй онолын хувьд шууд хэрэглэж болдоггүй.

Энэхүу хүчтэй холбоост задаргааны онцлог нь зөвхөн асимптотик задаргаанд хүргэдэг хөндөлтийн онолоос ялгаатай бөгөөд нийлэлтийн тодорхой мужтай. Тухайн муж дотор латтис гэйж онолоор кварк конфайнмент үзэгдлийн талаар мэдээлэл авахад энэ аргыг хэрэглэдэг. Мөн энэ аргыг Монте Карло симуляцийн үр дүнг шалгахад хэрэглэдэг. Хүчтэй холбоост задаргаa бол ямар нэг фазын шилжилтийг тайлбарлахад маш сайн шалгарсан арга юм.

Дээр дурдсанчлан Вилсоны гогцооны магадлалын утгын шинж чанараар гэйж инвариант физик хэмжигдэхүүний утгыг тодорхойлж өөр өөр фазуудыг ялгах боломжтой байдаг учраас энэ бол маш чухал юм.

Функционал интегралын төлөвт эвклидийн квант орны онол ба статистик механикын хоорондын аналогоор тасралтгүй физикийн холбоосын тогтмол $\mathrm{g}^{2}$ нь температуртай ижил үүрэг гүйцэтгэдэг. Хүчтэй холбоос буюу бага $\beta$-ийн хувьд $\left(\beta=2 \mathrm{~N} / \mathrm{g}^{2}\right)$ латтис гэйж онол нь их температур дахь статистик системд харгалздаг. Тиймээс хүчтэй холбоост задаргааг статистик механикийн их температур дахь кластер задаргааны аргаар гаргадаг.

Тэг температурт, конфайнмент фазад вортексийн чөлөөт энергийн шинж чанар нь Вилсон гогцооны магадлалын утгын шинж чанартай адилаар талбайн хуулийг дагадаг. Энэ талбайн коэффициент нь статик кваркуудын хоорондох таталцлын коэффициенттэй тэнцүү.

1981 онд Мюнстер цэвэр латтис гэйж онолоор, SU(2) гэйж груп ашиглан, 4-н хэмжээст тохиолдолд вортексийн чөлөөт энергээс хүчтэй холбоост задаргааг арван хоёрдугаар эрэмбэ хүртэл

$$
\begin{aligned}
\sigma_{\infty}= & -\ln u-4 u^{4}+8 u^{6}-12 u^{4} v-56 u^{8}+120 u^{10}-168 u^{8} v-72 u^{6} v^{2}-12 v^{5}-\frac{4732}{3} u^{10} v- \\
& -888 u^{10} v-396 u^{8} v^{2}-48 u^{6} v^{2}-48 u^{4} v^{4}+36 v^{6}-48 u^{9} w-24 v^{5} w u^{-1} \ldots= \\
= & -\ln u-4 u^{4}-\frac{176}{8} u^{8}-\frac{10936}{405} u^{10}-\frac{1532044}{1215} u^{12}-\cdots .
\end{aligned}
$$

гэж тооцсон [13]. Мөн 1980 онд Кройц $S U(2)$ онолоор Монте Карло арга ашиглан глюоны урсгалын хоолойн таталцлын коэффициентын утгыг гаргаж авсан [14]. Дээрх хоёр үр дүнг хамтад нь $\beta$-аас хамааруулан Зураг 2-д зуржээ. Мөн энэ зурагт $\exp \left(-\frac{6 \pi}{11}(\beta-2)\right)$ томъёогоор харуулсан дахин нормчлолын групээр илэрхийлэгдэж гарсан сул холбоост задаргааны (weak coupling expansion) муруйг багтаасан байна [14]. Хүчтэй холбоост задаргааны арван хоёрдугаар эрэмбийн үр дүнтэй харьцуулах үүднээс хамгийн бага эрэмбийн үр дүнг мөн багтаасан. Зургаас харахад $2.2<\beta<2.5$ байх мужид МК дата нь сул холбоост задаргааны экспоненциал муруйг дагаж байна. Өөрөөр 
хэлбэл таталцлын коэффициент нь хүчтэй холбоост шинж чанараас сул холбоост шинж чанар руу шилжиж байна. Мөн хүчтэй холбоост задаргааг арван хоёрдугаар эрэмбэ хүртэл тооцоход энэ задаргааны муруй нь мөн сул холбоост задаргааны муруйг дагаж байгаа нь харагдаж байна. Үүнийг roughening transition гэж нэрлэдэг. Өөрөөр хэлбэл, $\beta$-ийн тодорхой нэг утганд хүрээд дээрх шилжилт болохыг онолоор болон симуляцийн үр дүнгээр аль алинаар нь батлан харуулж байна.

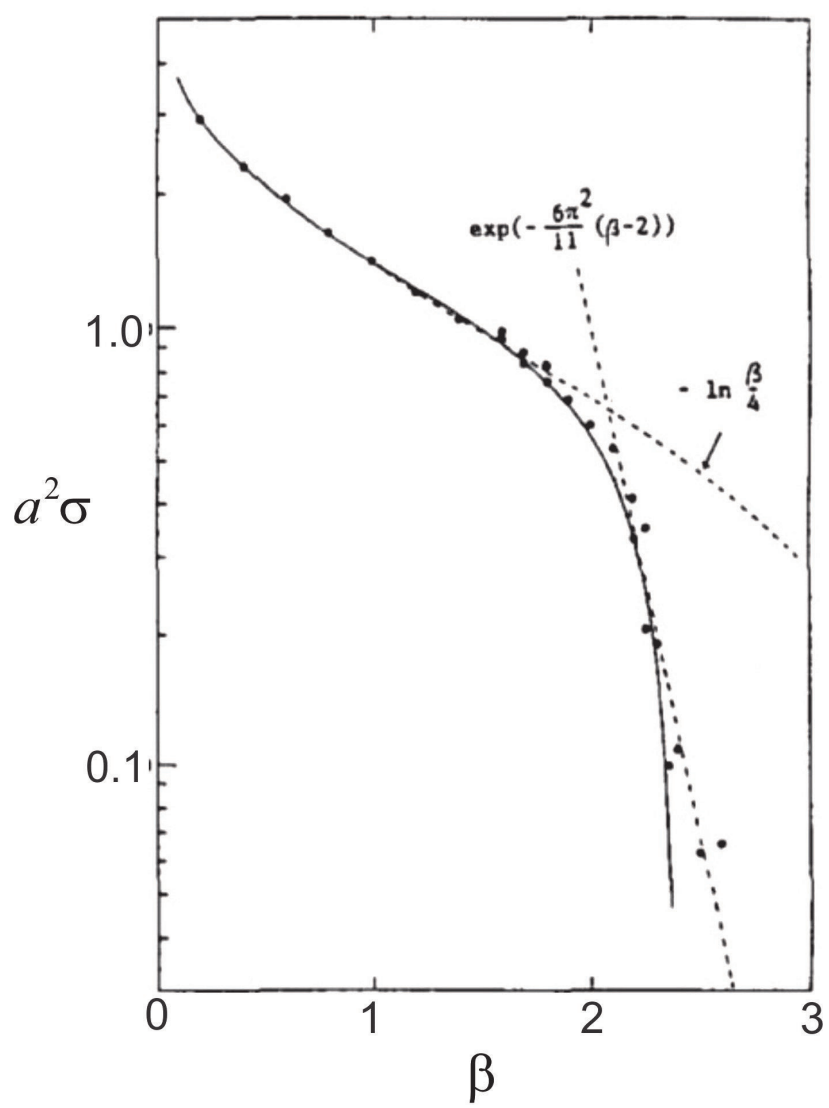

Зураг 2: Глюоны орны таталилын коэффициент холбоосын тогтмолоос хамаарах хамаарал [13].

2008 онд Мюнстер нар хүчтэй холбоост задаргааг тодорхой $N_{\tau}$-тай буюу тодорхой температуртай үед эхний хэдэн эрэмбийг

$$
f\left(N_{\tau}, u\right)=-\frac{3}{N_{\tau}} u^{4 N_{\tau}} c^{N_{\tau}}\left[1+12 N_{\tau} u^{4}-\frac{1556}{81} N_{\tau} u^{6}+\left(83 N_{\tau}^{2}+\frac{41417}{243} N_{\tau}\right) u^{8}+O\left(u^{10}\right)\right]
$$

гэж тооцсон. Энд $u=\frac{I_{2}(\beta)}{I_{1}(\beta)}=\frac{1}{4} \beta-\frac{1}{96} \beta^{3}+\frac{1}{1536} \beta^{5}-\frac{1}{23040} \beta^{7}+O\left(\beta^{9}\right)$

Цаашидын судалгааны ажилд энэхүу тодорхой температур дахь хүчтэй холбоост задаргааны үр дүнг симуляцаас гаргаж авсан үр дүнтэй харьцуулах шаардлагатай юм. 


\section{ГЛЮОНЫ УРСГАЛЫН ХООЛОЙН ӨРГӨН}

Таталцлын коэффициентын утга хүчтэй холбоост мужаас сул холбоост мужруу шилжих шилжилт болж байгаa сигналыг мөн глюоны урсгалын хоолойн бүтэц шинж чанараас тодорхойлж болдог. Үүний тулд бид глюоны урсгалын хоолойн өргөн хэмээх хэмжигдэхүүнийг авч үзэх хэрэгтэй. Уг хоолой доторх энергийн нягтын хөндлөн түгэлтийг бид глюоны орны хоолойн физик өргөн гэж үздэг. Өнгөт орны энергийн нягтыг [15]

$$
\varepsilon(x) \propto\left\langle q \bar{q}\left|\operatorname{Tr} E^{2}(x)\right| q \bar{q}\right\rangle-\langle q \bar{q} \mid q \bar{q}\rangle-\left\langle\operatorname{Tr}^{2}(x)\right\rangle
$$

тэгшитгэлээр тооцдог бол латтис дээр тооцоолохдоо Вилсоны гогцоо болон плакетийн корреляцаар

$$
\varepsilon(x) \propto \frac{\left\langle W(C) P_{x}\right\rangle-\langle W(C)\rangle\left\langle P_{x}\right\rangle}{\langle W(C)\rangle}
$$

гэж илэрхийлдэг. Харин тодорхой температуртай тохиолдолд Поляковын гогцоо, плакетийн корреляцаар дараах

$$
\varepsilon(x) \propto \frac{\left\langle L(0) L(R) P_{x}\right\rangle-\langle L(0) L(R)\rangle\left\langle P_{x}\right\rangle}{\langle L(0) L(R)\rangle}
$$

томъёогоор тооцоолдог. Эндээс энергийн нягтын хөндлөн түгэлтийг

гэж олно.

$$
D^{2}=D^{2}(R / 2)=\frac{\int d^{2} x_{\perp} x_{\perp}^{2} \varepsilon(x)}{\int d^{2} x_{\perp} \varepsilon(x)}
$$

1981 онд Люшер нар хүчтэй холбоост задаргааны аргаар глюоны урсгалын хоолойн өргөнийг тэг температурт мөн арван хоёрдугаар эрэмбэ хүртэл

$$
D_{\infty}^{2}=4\left\{u^{4}+2 u^{6}+\frac{92}{3} u^{8}+\frac{37727}{405} u^{10}+\frac{1412551}{1215} u^{12}+\cdots\right\}
$$

гэж бодсон байдаг [15]. Энэ цувааг холбоосын тогтмолоос хамааруулан Зураг 3-д харуулав. Зургаас харахад конфайнмент фазад бидний мэдэх эффектив утасны (string) флуктуацаас гарч ирдэг хамаарлын дагуу $\beta=2$ хүртэл 0 -оос 0.5 хүртэл монотон өсөж байна, гэвч $\beta \geq 2$ болоход өсөлт нь илүу хурдан болж байгаа нь харагдаж байна. Энэ нь Кройц [14]-ын Монте Карло тооцооллоос гарч ирсэн таталцлын коэффициент хүчтэйгээс сул холбоосруу шилждэг холбоосын тогтмолын утгатай тохирч байна. 


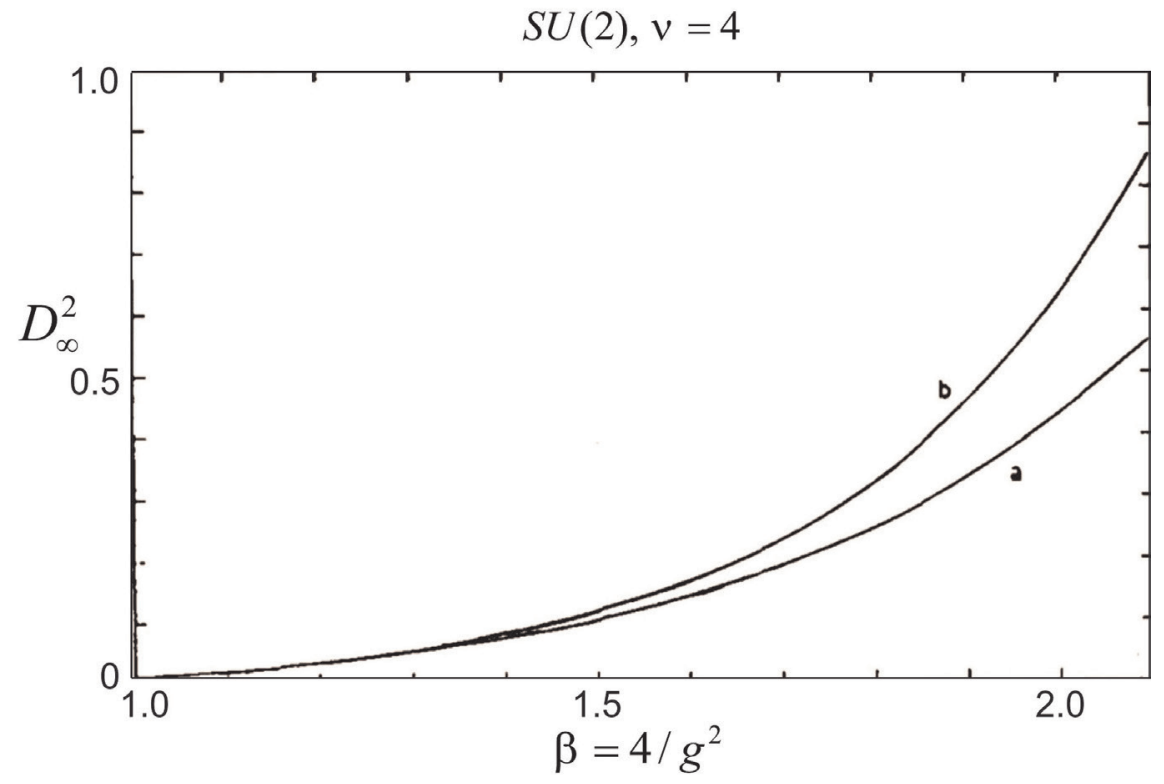

Зураг 3: Глюоны урсгалын хоолойн өргөн $\beta$-аас хамаарах хамаарал [15].

Мөн энэ [15] ажилд хэрэв тасралтгүй хязгаарт $D_{\infty}^{2}<\infty$ байдаг бол $\beta \geq 2$ байхад $\sigma \cdot D_{\infty}^{2}$ нь тодорхой нэг тогтмол утганд хүрэх ёстой гэж үзэн [13]-д $\sigma$-г бодож гаргасан хүчтэй холбоост цувааг ашиглан

$$
\left(\sigma D_{\infty}^{2}\right)^{-1}=\frac{-1}{4 u^{4} \ln u}\left\{1-2 u^{2}-4 u^{4}\left(\frac{20}{3}+\frac{1}{\ln u}\right)+4 u^{6}\left(\frac{2179}{405}+\frac{2}{\ln u}\right)-u^{8}\left(\frac{244903}{1215}-\frac{48}{\ln u}-\frac{16}{(\ln u)^{2}}\right)+\cdots\right\}
$$

гэж гаргаж авсан. Харгалзах 6 ба 8-p эрэмбийн муруйнуудыг-аас хамааруулан зурсан байдаг бөгөөд Зураг 4-д харууллаа. Ингэхэд $\left(\sigma \cdot D_{\infty}^{2}\right)^{-1}$ нь тодорхой нэг утганд хүрч байна гэхээсээ илүүтэйгээр ойролцоогоор $\beta \approx 1.9$ дээр тэг болж байна. Энэ утга нь $\beta \geq 2$ байх шилжилтийн мужийн яг доор нь байгаа юм. Энэ үед глюоны урсгалын хоолойн өргөнийг сарниж байна гэж үздэг бөгөөд энэхүҮ холбоосын тогтмолын утгыг roughening утга гэж нэрлэдэг. Roughening цэг дээр глюоны орны хоолойн гадаргуу бүхэлдээ

$$
\frac{a_{1}}{\left(a_{2}+x_{\perp}^{2}\right)^{3}}
$$

делокализаци (delocalized) болдог боловч тодорхой бодит хэвээр байх ба тодорхой таталцалтай хэвээр байдаг.

Бид симуляцаас гарсан үр дүнгүүдийг боловсруулан глюоны урсгалын хоолойн өргөнийг тооцоолж, кваркуудын хоорондох зайнаас болон холбоосын тогтмолоос хамаарах хамаарлыг олох зорилготой. Глюоны урсгалын хоолойн өргөнийг тооцохдоо уг хоолой доторх хромоцахилгаан ба хромосоронзон орнуудын хөндлөн түгэлтэнд Кулоны 


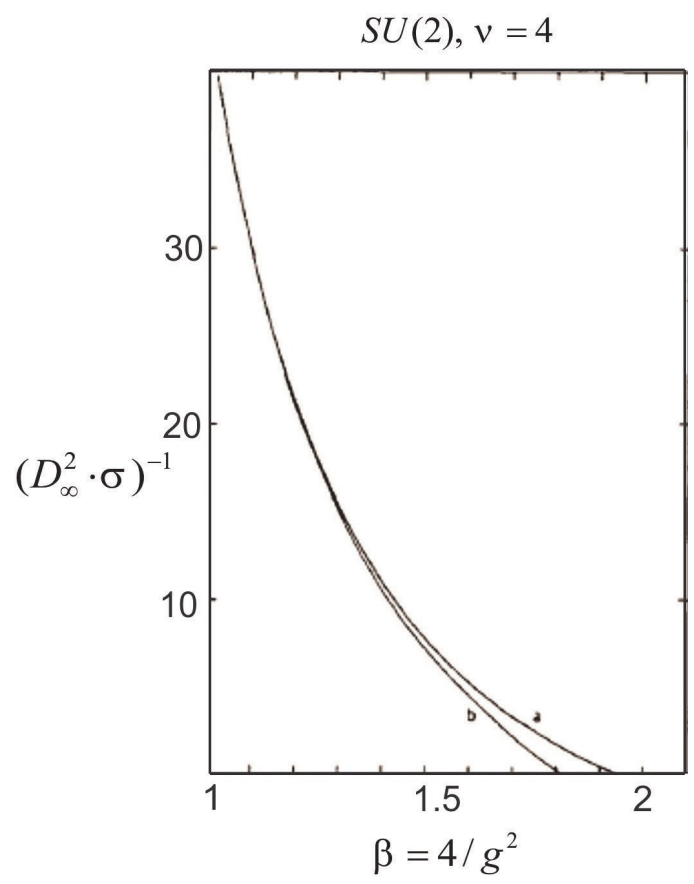
Зураг 4: $\left(\sigma \cdot D_{\infty}^{2}\right)_{6}^{-1}$ бь $\beta$ аас хамаарах хамаарал. а ба в нь харгалзан

болон экспоненциал

$$
b_{1} e^{-b_{2} x_{\perp}}
$$

[16] функцуудаар фит хийж фитийн параметрийн утгуудаар тэгшитгэл 9-ийн интегралыг бодож өргөнийг тооцоолсон. Хромосоронзон орны байгуулагчууд болон хромоцахилгаан орны перпендикуляр байгуулагчийн утгууд нь ойролцоо харин цахилгаан орны параллель байгуулагчийн утга нь илүY их утгатай байгааг [3]т тооцоолж харуулсан байдаг. Иймээс бид зөвхөн цахилгаан ба соронзон орны параллель байгуулагчуудад фит хийж үр дүнг тооцоолсон. Манай тохиолдолд соронзон орны параллель байгуулагчийн датаг кулоны функц

$$
\frac{1}{2 \beta} B_{\|}^{2}\left(r, x_{\perp}\right)=\frac{a_{1}}{\left(a_{2}+x_{\perp}^{2}\right)^{3}}
$$

сайн илэрхийлж байсан бол цахилгаан орны параллель байгуулагчид фит хийхэд нэмэлт экспоненциал функц

$$
\frac{1}{2 \beta} E_{\|}^{2}\left(r, x_{\perp}\right)=\frac{a_{1}}{\left(a_{2}+x_{\perp}^{2}\right)^{3}}+b_{1} e^{-b_{2} x_{\perp}}
$$

шаардагдаж байсан юм. Эндээс фитийн параметрүүдээр энергийн нягтын өргөнийг

хэмээн тооцоолсон.

$$
a^{-2} D^{2}=\frac{6}{b_{2}^{2}}
$$




\section{ХЭМЖИЛТ БА ҮР ДУН}

Хэмжилтийг 16 х $8^{2}$ х 4 хэмжээтэй латтис дээр, хоёр кваркийн хоорондох зайг 4a-8a хүртэлх утганд хийсэн. $N_{\tau}=4$ үед деконфайнмент фазын шилжилт болох критик холбоосын тогтмолын утга $\beta_{c}=2.2985 \pm 0.0006$ байдаг бол бид конфайнмент фазад хэмжилт хийнэ. Мөн хүчтэй холбоост мужаас сул холбоост мужруу шилжих шилжилтийн тэг температур дахь холбоосын тогтмолын утгатай харьцуулах ёстой. Дээрх хоёр шалгууртаа нийцүүлэн бид холбоосын тогтмолын $\quad \beta=1.6,1.7,1.8,1.9,2.0,2.1,2.2$ гэсэн утгуудыг сонгож аван хэмжилтийг гүйцэтгэсэн. 400000 удаагийн хэмжилтийг боловсруулан статистик боловсруулалт хийв.

Фитийн чөлөөт параметрийн утгууд болон 16 томъёогоор бодож гаргасан урсгалын хоолойн өргөний утгыг Хүснэгт 1-д үзүүлэв. Дараах үр дүнгүүд нь бүгд физик нэгжрүу шилжүүлээгүй буюу латтисын алслалт $a$-ын нэгжээр илэрхийлэгдсэн болно.

Хүснэгт 1: Фитийн чөлөөт параметрийн утга ба глюоны урсгальвн хоолойн өргөн

\begin{tabular}{|c|c|c|c|c|c|c|c|}
\hline$r / a$ & $\beta$ & $a_{1}$ & $a_{2}$ & $b_{1}$ & $b_{2}$ & $a^{-2} D^{2}$ & $\chi$ \\
\hline \multirow{7}{*}{4} & 1.6 & $8.36(15.25)$ & $2.55(1.79)$ & $-0.56(31)$ & $0.87(44)$ & $7.92(37)$ & 0.154 \\
\hline & 1.7 & $3.49(14.00)$ & $0.94(1.19)$ & $3.19(3.44)$ & $1.35(69)$ & $3.24(94)$ & 0.0034 \\
\hline & 1.8 & $-616.14(4.90)$ & $24585.9(6.5 \mathrm{E}+16)$ & $-2.70(3.29)$ & $2.56(1.36)$ & $0.91(22.12)$ & 0.0092 \\
\hline & 1.9 & $9708.2(2.09 \mathrm{E}+04)$ & $77.80(60.36)$ & $0.23(02)$ & $3.72(1.73)$ & $0.35(6.12)$ & 0.0062 \\
\hline & 2.0 & $-5136(9227)$ & $66.98(43.47)$ & $0.13(1)$ & $0.95(9)$ & $6.64(2.27)$ & 0.6075 \\
\hline & 2.1 & $1.52(42)$ & $4.55(52)$ & $0.053(1)$ & $1.29(5)$ & $3.61(93)$ & 0.2695 \\
\hline & 2.2 & $0.57(14)$ & $2.93(26)$ & $0.0100(6)$ & $0.65(4)$ & $14.20(1.47)$ & 5.17 \\
\hline \multirow{7}{*}{6} & 1.6 & $2.45 \mathrm{E}+05$ & $0.09(62.93)$ & $-0.09(4)$ & $-0.04(16)$ & $3750(96)$ & 0.02656 \\
\hline & 1.7 & $-9.05 \mathrm{E}+05$ & $316.59(1737.00)$ & $0.17(7)$ & $0.097(17)$ & $740.74(45.34)$ & 0.0534 \\
\hline & 1.8 & $10138.7(1.5 \mathrm{E}+04)$ & $37.62(21.1)$ & $-0.21(8)$ & $0.17(14)$ & 207.61(19.76) & 0.0942 \\
\hline & 1.9 & $3.39(14.28)$ & $0.94(1.26)$ & $-3.24(2.83)$ & $1.23(16)$ & $3.96(3.12)$ & 0.0515 \\
\hline & 2.0 & $0.008(2)$ & $-0.47(7)$ & $0.22(34)$ & $0.76(8)$ & $10.38(2.52)$ & 0.31 .65 \\
\hline & 2.1 & $165(430)$ & $26.66(26.39)$ & $0.02(1)$ & $1.97(1.89)$ & $1.54(23.02)$ & 0.2059 \\
\hline & 2.2 & $0.43(82)$ & $4.90(3.39)$ & $0.010(2)$ & $0.62(15)$ & $15.60(5.80)$ & 1.36 \\
\hline \multirow{7}{*}{8} & 1.6 & $2.54 \mathrm{E}+07(3.58 \mathrm{E}+08)$ & $646(3041)$ & $0.20(4)$ & $0.02(8)$ & $15000(96)$ & 0.0684 \\
\hline & 1.7 & $-1.68(4.67)$ & $2.38(2.36)$ & $0.01(10)$ & $1.22(9.73)$ & 4.03(191.41) & 0.0991 \\
\hline & 1.8 & $18.54(29.09)$ & $5.23(54.32)$ & $0.33(7)$ & $0.33(9)$ & $0.55(6.54)$ & 0.0754 \\
\hline & 1.9 & $-189864(1.52 \mathrm{E}+06)$ & $202.02(560.0)$ & $0.06(1)$ & $0.04(10)$ & $113.42(2.08)$ & 0.0514 \\
\hline & 2.0 & $-65.46(165.7)$ & $12.05(11.31)$ & $0.029(21)$ & $-0.10(23)$ & $600(55.2)$ & 0.0842 \\
\hline & 2.1 & $-6.51 \mathrm{E}+06(4.44 \mathrm{E}+07)$ & $560(1224)$ & $0.050(9)$ & $0.10(7)$ & $495(15.27)$ & 0.1238 \\
\hline & 2.2 & $0.22(30)$ & $3.73(1.79)$ & $-0.003(1)$ & $-0.01(12)$ & $15000(144)$ & 0.23 \\
\hline
\end{tabular}

Зураг 5-д холбоосын тогтмолын утга тус бүрийн хувьд глюоны урсгалын хоолойн өргөний зайнаас хамаарах хамаарлыг зурж Үзүүллээ. Харин Зураг 6- д дээрх зургуудаа хамтад нь нэг хавтгайд зурж хамаарлыг харуулав. Глюоны урсгалын хоолойн өргөн кваркуудын хоорондох зайнаас хамаарч шугаман өргөсдгийг [17] харуулсан байдаг. Эдгээр хоёр зургаaс харахад бидний үр дүн дээрх ажлын дүгнэлттэй ерөнхий хамаарлаараа тохирч байгаa нь харагдаж байна. 
Зураг 7-д урсгалын хоолойн өргөн холбоосын тогтмолоос хамаарах хамаарлыг $r=4 a, \quad 6 a 8 a$ байх тохиолдлуудад зурж үзүүллээ. Зураг 8-д Зураг 7-ын графикуудыг нэгтгэн зурсан. Зургаас харахад $r=4 a$
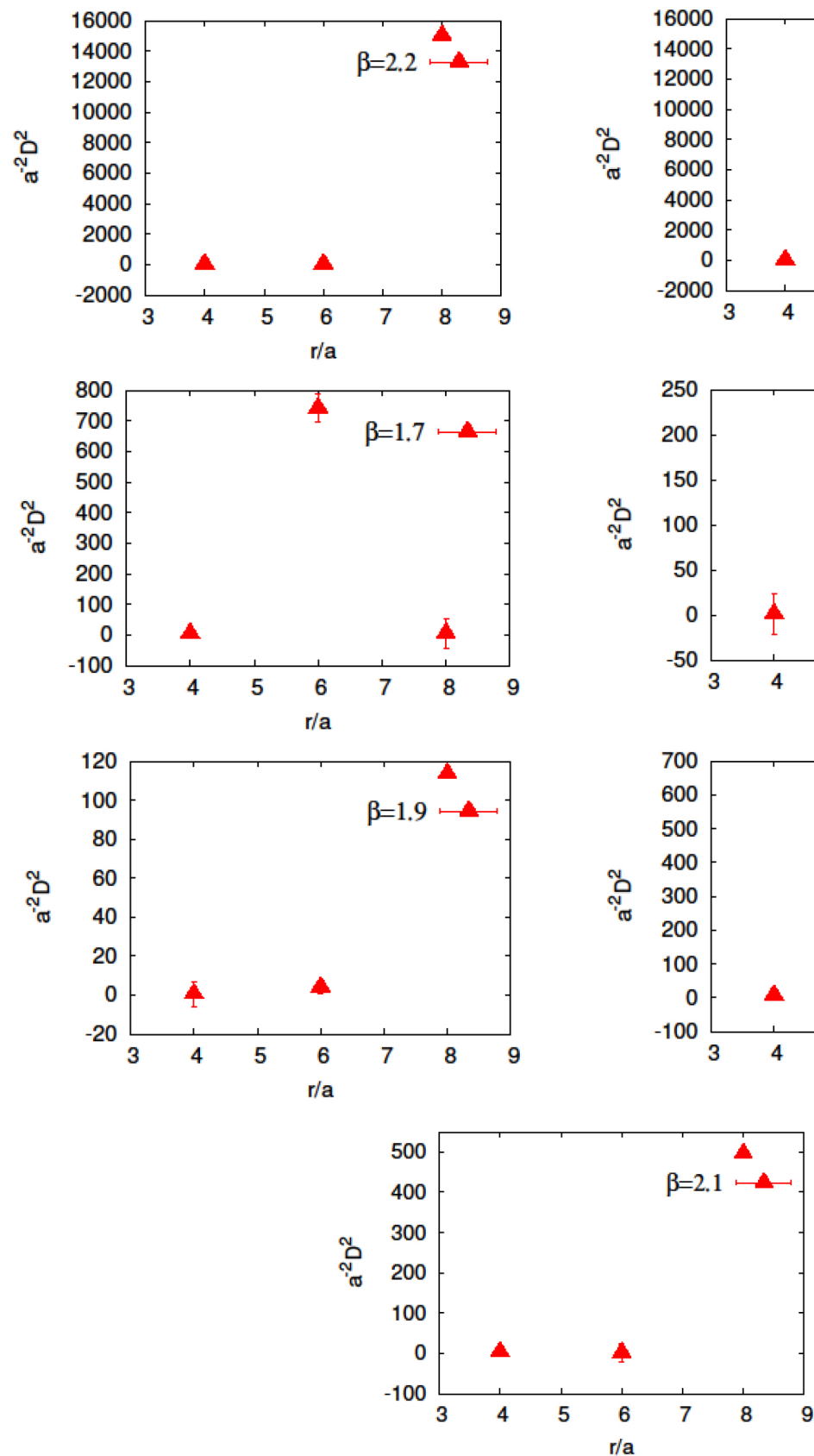

Зураг 5: Глюоны урсгалын хоолойн өргөн холбоосын тогтмолоос хамаарах хамаарал.

үед $\beta=2.2$ дээр бага зэргийн өргөсөлт ажиглагдсан бол $r=8 a$ байх үед $\beta=1.6$-аaс 2.1 тогтвортой байж байгаад $\beta=2.2$ утганд огцом өргөсөж байна.
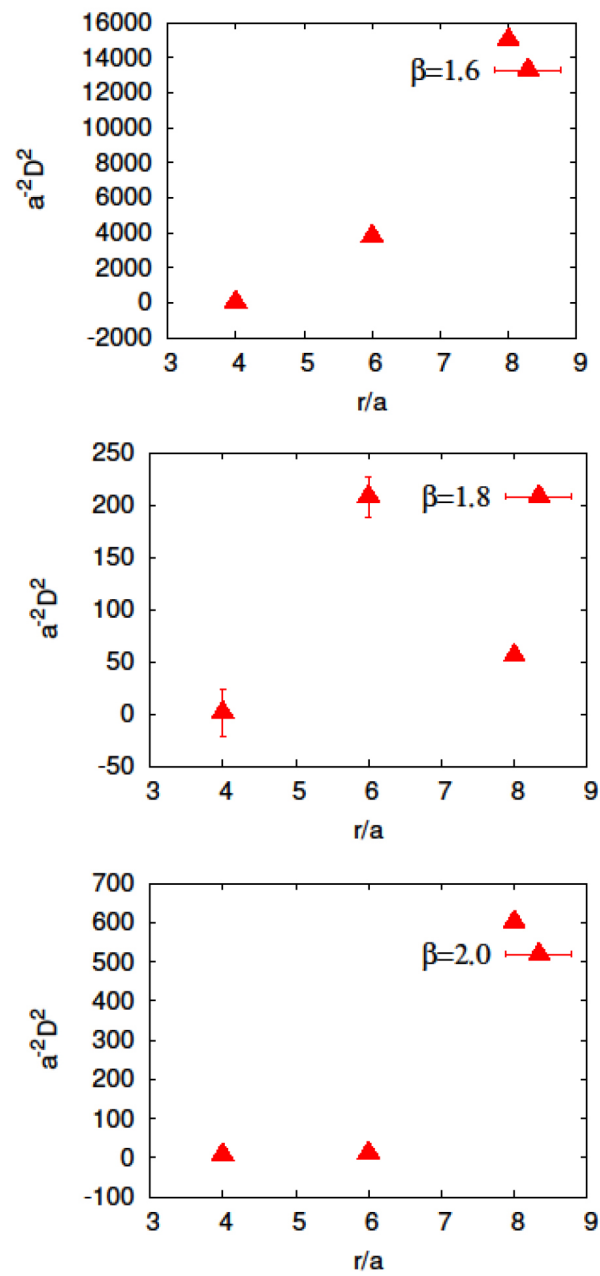


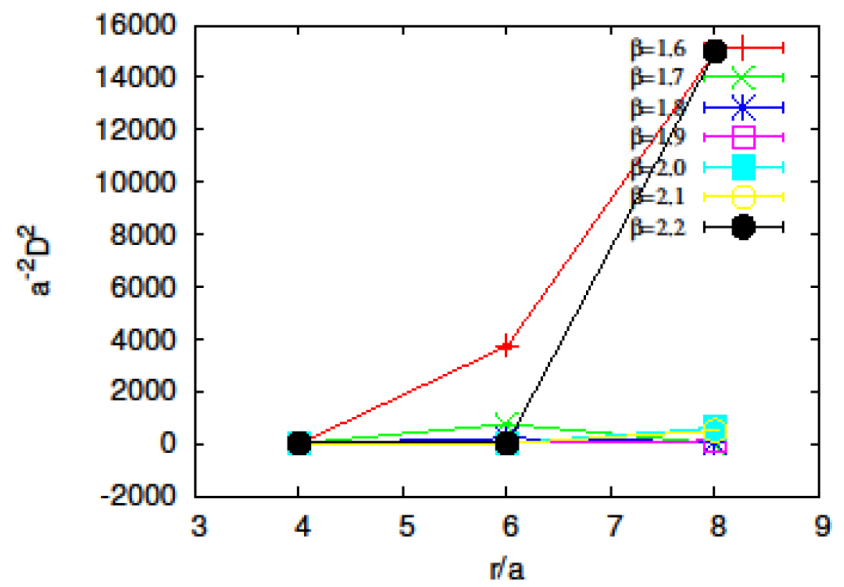

Зураг 6: Глюоны урсгалын хоолойн өргөн кваркуудын хоорондох зайнаас хамаарах хамаарал.
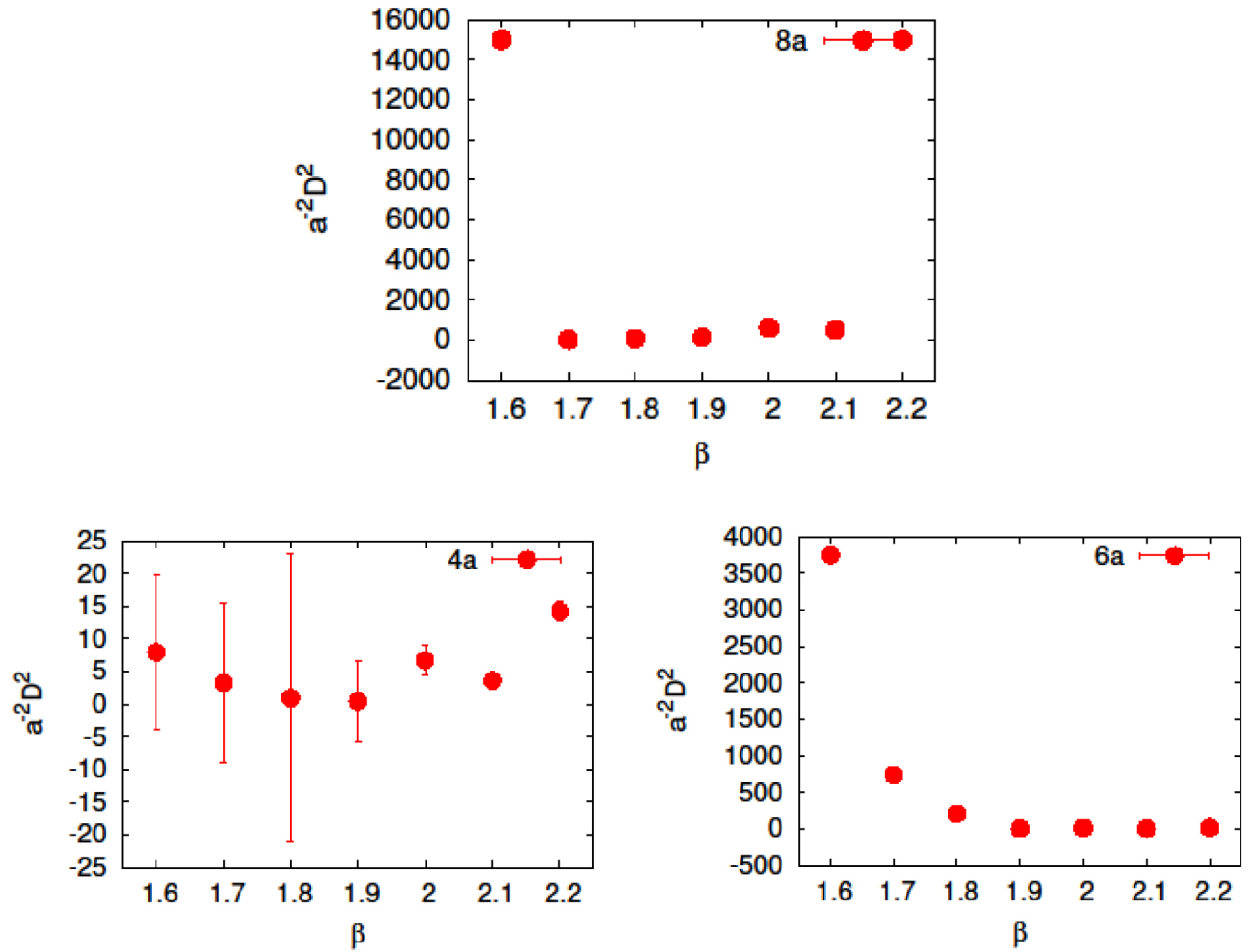

Зураг 7: Глюоны урсгалын хоолойн өргөн холбоосын тогтмолоос хамаарах хамаарал. 


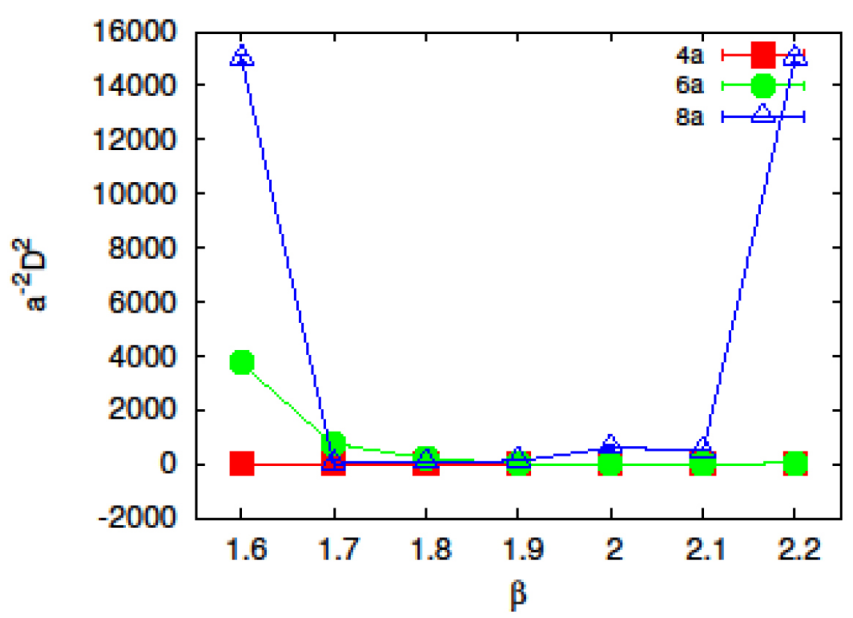

Зураг 8: Глюоны урсгалын хоолойн өргөн холбоосын тогтмолоос хамаарах хамаарал.

\section{ДҮГНЭЛТ}

Бид энэ ажлаар тэг биш температурт, конфайнмент фазад глюоны урсгалын хоолойн бүтэц шинж чанар холбоосын тогтмол ба хоёр кваркийн хоорондох зайнаас хамаарч хэрхэн өөрчлөгдөж байгааг судлав.

Латтис онолоор бага $\beta$-ийн утганд симуляци хийж гүйцэтгэхэд үүсэх утгууд нь флуктуац ихтэй гардаг учраас бидний үр дүн статистик шуугиан ихтэй, дүгнэлт хийхэд хүндрэлтэй байсан хэдий ч дараах дүгнэлт хийлээ. Хоёр кваркийн хоорондох зай холдоход глюоны урсгалын хоолойн өргөн өргөсдөгийг дахин батлан харуулав. Харин холбоосын тогтмолын тодорхой мужид уг өргөн монотоны буюу тогтвортой байсан бол тодорхой нэг утганд огцом өргөсөж байна гэсэн дүгнэлтийг хийлээ. Эндээс тодорхой температурт глюоны урсгалын хоолойн өргөн сарниж байна гэж дүгнэв. Энэ утга манай тохиолдолд буюу $N_{\tau}=4$ байхад $\beta=2.2$ байв. Холбоосын тогтмолын энэ утга нь $0.79 T$-д харгалзана. Иймээс тэг температурт $\beta=1.9$ байдаг холбоосын тогтмолын утга тодорхой температурт өөр байна.

Цаашид илүү том латтис дээр $0.79 T_{c}$-ийн эргэн тойрон дахь холбоосын тогтмолын утгуудад хэмжилт хийх шаардлагатай гэсэн дүгнэлтэнд хүрлээ. Түүнчлэн таталцлын коэффициентийг тооцоолж, холбоосын тогтмолоос хамаарах хамаарлыг гаргана. 


\section{НОМ ЗYЙ}

[1] O. Kaczmarek, F. Karsch, E. Laermann and M. Lutgemeimer, Phys. Rev. D62 034021, 2000.

[2] O. Kaczmarek, F. Karsch, P. Petreczky and F. Zantow, Phys. Rev.D70 074505, 2004.

[3] S. Chagdaa, Flux tube profiles at high energy, Doctoral dissertation, 2008.

[4] S. Chagdaa, E. Laermann, G. Gombojav and E. Galsandorj, Mongolian Journal of Physics 33, 2016.

[5] M. Creutz, Quarks, Gluons and Lattices, Cambridge university Press, 1983.

[6] N. Cardoso and P. Bicudo, Lattice QCD computation of the SU(3) String tension critical curve, Phys. Rev. D85 077501, 2012

[7] J.M. Drouffe, Nucl. Phys. B170 [FS1] 91, 1980.

[8] G. Munster and P. Weisz, Nucl. Phys. B180 [FS2] 13, 1981.

[9] G. Munster and P. Weisz, Nucl. Phys. B180 [FS2] 330, 1981.

[10] J. M. Drouffe and J. B. Zuber, Nucl. Phys. B180 [FS2] 253, 1981.

[11] J. M. Drouffe and J. B. Zuber, Nucl. Phys. B180 [FS2] 264, 1981.

[12] A. Hasenfratz, E. Hasenfratz and P. Hasenfratz, Nucl. Phys. B180 [FS2] 353, 1981.

[13] G. Munster, Nucl. Phys. B180 [FS2] 23, 1981.

[14] M. Creutz, Phys. Rev. D21 2308, 1980.

[15] G. Munster, Nucl. Phys. B180 [FS2] 1, 1981.

[16] R. Sommer, Nucl. Phys. B306 181, 1988

[17] A. Allais and M. Gaselle, Journal of High Energy Physics, JHEP 0901 073, 2009. 


\title{
THE ROUGHENING TRANSITION IN SU(2) LATTICE GAUGE THEORY AT FINITE TEMPERATURE
}

\author{
Ch. Sodbileg ${ }^{I}$, G. Enkhtuya ${ }^{1 *}$ \\ ${ }^{I}$ Institute of Physics and Technology, MAS, Mongolia \\ *corresponding author, e-mail: enkaa_tuyaa@yahoo.com
}

\begin{abstract}
In this work, we have tried to observe the roughening transition in $\mathrm{SU}(2)$ pure gauge theory at finite temperature by performing numerical simulation which occurs at zero temperature in confined phase.

The physical with of the flux tube have determined from the transverse profiles of chromo electric component of the field strength in the flux tube and we have investigated the width as a function of the interquark distance and the temperature. We have confirmed that the width of the flux tube increases with $q \bar{q}$ separation and also showed that the width rises steeply when the coupling constant has reached at a certain value.
\end{abstract}

Key words: Lattice $Q C D$, quark confinement, roughening transition, string tension, flux tube; 